\title{
The Political Legitimacy of Global Governance and the Proper Role of Civil Society Actors
}

\author{
Eva Erman ${ }^{1}$
}

Published online: 19 December 2017

(C) The Author(s) 2017. This article is an open access publication

\begin{abstract}
In this paper, two claims are made. The main claim is that a fruitful approach for theorizing the political legitimacy of global governance and the proper normative role of civil society actors is the so-called 'function-sensitive' approach. The underlying idea of this approach is that the demands of legitimacy may vary depending on function and the relationship between functions. Within this functionsensitive framework, six functions in global governance are analyzed and six principles of legitimacy defended, together constituting a minimalist account of political legitimacy. This account suggests that civil society actors may strengthen political legitimacy by performing five of these functions under certain conditions and insofar as the proposed normative political principles are fulfilled: problem identification, agenda-setting, implementation, enforcement and monitoring, and evaluation. The second claim is critical and is chiselled out against the backdrop of this function-sensitive account, through which I demonstrate that much vagueness and confusion with regard to the proper role of civil society actors for strengthening the political legitimacy of global governance could be traced to the so-called 'transmission belt' model, which has gained popularity in international political theory. This model depicts civil society as a transmission belt between the public sphere and decision-making loci, where it is assumed that civil society actors contribute to the strengthening of political legitimacy by transmitting peoples' preferences, beliefs, and opinions from the former to the latter space by indirectly or directly influencing the decision-making. It is argued that this picture is misleading and generates erroneous prescriptions of how civil society actors should act to increase political legitimacy.
\end{abstract}

Eva Erman

eva.erman@statsvet.su.se

https://www.statsvet.su.se/eva_erman

1 Department of Political Science, Stockholm University, Stockholm, Sweden 
Keywords Political legitimacy · Democracy · Global governance $\cdot$ Civil society $\cdot$ Transmission belt $\cdot$ Functions

International collaboration has traditionally consisted almost exclusively of interstate cooperation, often through international organizations such as the United Nations, the African Union, and the World Trade Organization. Since the 1990s, however, fundamental transformations have gradually taken place, witnessing a shift from interstate cooperation to more complex forms of governance, involving not only states but also a wide range of civil society actors, such as nongovernmental organizations (NGOs) and social movements. Through this shiftoften described as a 'transnational turn' in global governance-the constitution, function and policy responsibilities of global governance arrangements have undergone profound changes. Today, the involvement of civil society actors takes places in all policy areas of global governance, in all regions, and concerning all policy functions. A total absence of access to global governance arrangements is extremely rare. Even the International Monetary Fund, which is the most closed of the economic institutions, has opened up by consulting civil society in association with its summits (Tallberg et al. 2013, pp. 4-5).

This opening up of global governance to civil society is largely seen as a welcome transformation in global politics generating not only a deeper and broader collaboration due to the weakening of states' concern with national sovereignty, but also a democratization of global governance through increased transparency, inclusion, and openness towards citizens around the world. But apart from the wide agreement on the general desirability of this transformation, we still know very little about the specific reasons for why and how this is a welcome development. In the last couple of years, important contributions have been made in the empirical literature in the form of systematic analyses of where, how and why for example international organizations involve civil society actors in global decision-making, including a wide range of organizations compared across policy areas, regions, and functions (Tallberg et al. 2013; Koremenos 2013; Bloodgood 2011; Green and Colgan 2013). However, the same systematic attempt to address the question of where, how and why global governance arrangements should involve civil society actors in political processes has so far not been made in political theory. In light of the diversity of international arrangements exposed in these empirical studies, with different functions, policy responsibilities and authority, it seems likely that civil society actors ought to play different roles in the overall political process depending on what they are intended to do and in what kind of context.

On the one hand, the normative-theoretical literature on the role of civil society in global governance has generally been very optimistic of what civil society actors can and should achieve to strengthen the political legitimacy of global governance. On the other, political theorists typically theorize the role of civil society actors by relying on highly generalized assumptions about global governance, neglecting the rich variety of institutions and their different roles and aims. Furthermore, there is a tendency to use underspecified normative criteria where almost every instance of improved governance-such as increased participation, transparency, authenticity, or deliberation-is interpreted as instances of democracy and political legitimacy. 
In this paper, two claims are made. The main claim is constructive; it is argued that a fruitful approach for theorizing the political legitimacy of global governance and the proper normative role of civil society is what I call the 'function-sensitive' approach, which understands political legitimacy in relation to key functions in global governance. To my knowledge, the relationship between functions and political legitimacy has so far escaped systematic scrutiny in the normativetheoretical literature. The underlying idea of this approach is that the demands of legitimacy may vary depending on function and the relationship between functions. Within this function-sensitive framework, six main functions in global governance are analyzed and six principles of legitimacy defended, together constituting a minimalist account of political legitimacy. ${ }^{1}$ This account suggests that civil society actors may strengthen political legitimacy by performing five of these functions under certain conditions and insofar as the proposed normative political principles are fulfilled: in problem identification, agenda-setting, implementation, enforcement and monitoring, and evaluation. However, it is argued that civil society actors should not perform decision-making functions by aiming at directly or indirectly influencing law- and policy-making.

The second claim is critical and is chiselled out against the backdrop of this function-sensitive view, through which I demonstrate that much vagueness and confusion with regard to the proper role of civil society actors for strengthening the political legitimacy of global governance could be traced to the so-called 'transmission belt' model, which has gained popularity in international political theory. This model depicts civil society as a transmission belt between the public sphere and decision-making loci-or in the terminology used by its proponents, between the public space and the empowered space-where it is assumed that civil society actors contribute to the strengthening of political legitimacy by transmitting peoples' preferences, beliefs, and opinions from the public space to the empowered space by either indirectly or directly influencing the decision-making (Nanz and Steffek 2004, 2008; Dryzek 2006, 2011; Stevenson and Dryzek 2012; Kuyper 2016; Bäckstrand 2006; 2011). According to the function-sensitive approach, this picture is misleading and generates erroneous prescriptions of how civil society actors should act to increase political legitimacy.

The structure of the paper is as follows. The first section presents the basic assumptions of the function-sensitive approach ('The Function-Sensitive Approach: Basic Assumptions' section). Thereafter, this approach is adopted and the account of the political legitimacy of global governance is developed, consisting of six normative political principles regulating six main functions in global governance ('The Function-Sensitive Account of Political Legitimacy' section). Once this account is on the table, the proper role of civil society is analyzed and the predominant transmission belt model is criticized ('The Proper Role of Civil Society' section).

\footnotetext{
${ }^{1}$ By 'minimalist' I mean it is not a full-fledged theory. Rather, the six principles are considered central for the political legitimacy of global governance, but no claims are made with regard to them being necessary and/or jointly sufficient for an exhaustive account. It would thus better be described as a 'skeleton' of an account.
} 


\section{The Function-Sensitive Approach: Basic Assumptions}

In this section, I want to suggest that a function-sensitive approach to political legitimacy is fruitful for theorizing political legitimacy in global governance. ${ }^{2}$ Such an approach is tied to a conceptual framework that opens up space for a wide range of actors and institutions. In the normative-theoretical literature, political legitimacy is generally characterized as a virtue of political entities and the rules (policies and laws) made within them (Christiano 1996; Wellman 1996; Buchanan 2002). It is furthermore often assumed that principles of political legitimacy regulate the relationship between political entities that make, apply, and enforce rules, and the subjects to whom these rules apply (Erman 2016b, p. 32; Buchanan 2010; Buchanan and Keohane 2006; Valentini 2012). Hence, focus is directed at rule-making, which on a modern understanding concerns law- and policy-making. The problem from a function-sensitive view is that many global governance arrangements have other functions in global politics, such as international courts. While it seems objectionable to demand of such entities to become democratic in the traditional sense, it seems equally objectionable to allow them to exercise power without any requirements of legitimacy.

Apart from a focus on rule-making, the prevalent philosophical view of political legitimacy furthermore employs a rather strong understanding of the 'right to rule', which emphasizes the exclusive right to use coercion to secure compliance. As much as this notion may be fitting for a nation-state context, it seems unsuitable for global politics. None of the existing global governance arrangements rule or claim to rule coercively in this robust way, and there seems to be no reason to be so restrictive about which entities can potentially count as legitimate in the global domain (Erman 2016b, p. 30; Buchanan 2010, p. 82). In order to capture the main functions in global governance, a function-sensitive approach requires a broader conceptual framework.

As Rawls rightly points out, we need to know about the nature of the object that is supposed to be regulated by specific normative principles in order to properly theorize those principles (Rawls 1971, p. 29). In other words, we need a characterization of the object's core properties: insofar as normative principles are supposed to regulate the conduct and structure of a practice, this practice puts restrictions on what the principle may be, such that any candidate principle must satisfy a condition of applicability (Beitz 2014, p. 227; Erman 2016b, p. 35). On a function-sensitive approach, the concept of political legitimacy must be broad enough to be applicable to a wide range of functions apart from decision-making, but narrow enough to exclude those kinds of power that are not properly regulated by principles of political legitimacy but are better addressed by other principles, ideals, and values. Therefore, rather than the 'right to rule', the term political legitimacy in this paper is understood as 'the right to exercise political power', where political power means power exercised in the public domain. What this right

\footnotetext{
2 The account developed in 'The Function-Sensitive Approach: Basic Assumptions' and 'The FunctionSensitive Account of Political Legitimacy' sections draws heavily on and further advances thoughts from Erman (Forthcoming).
} 
entails in terms of obligations, however, will depend on what function the principle is supposed to regulate.

The next conceptual question of importance is what kinds of entities (agents and institutions) may fall under the concept of political legitimacy so understood and thus be candidates for being subjects of principles of legitimacy. It seems reasonable to presume that not any object that exercises power in the global public domain would constitute such a candidate. Even on a broad understanding, two features stand out as important. First, it seems plausible to hold on to the requirement that public power be exercised in a purposeful way, i.e. that it is not the result of unintended patterns of behavior. Hence, objects of the concept of political legitimacy must be agent centric (see Hurrell and Macdonald 2012). The reason is this: if entities do not act in intentional ways, affected subjects are not able to hold them to account and if accountability is not possible, the concept of legitimacy is not applicable (Erman 2016b, p. 35). Second, their exercise of power has to be systematic. For while the legitimate regulation of public power calls for common legal and political arrangements, we cannot establish an institution as soon as an agent projects power over another agent. What is constitutive of legal and political institutions is their relatively stable and sluggish structure (Erman 2014a, 2016b, p. 36$).^{3}$

Within this conceptual framework, the function-sensitive approach adopted here assumes that the content and justification of principles of political legitimacy is dependent on (a) the different functions in global governance and (b) the relationship between these functions. This means that the demands of legitimacy cannot be decided by looking at one function in isolation from other key functions. So, for example, if agents and institutions implement public policies, we need to know how they got the mandate to do so (e.g. by what agent or institution, and through what exercise of political power) to decide what legitimacy may require.

\section{The Function-Sensitive Account of Political Legitimacy}

The account developed in this section is best described as ideal-theoretical in the sense that it is developed under permissive feasibility constraints. ${ }^{4}$ Thus, the nature of the argument, consisting of abstract and comprehensive theorizing, is such that I will not be able to address many important concerns in relation to political legitimacy in global governance, not least relating to institutional design and

\footnotetext{
${ }^{3}$ Even if there might be disagreement about details, I am quite certain that this conceptual framework is accommodating enough to be acceptable also by proponents of the so-called 'transmission belt' model (discussed in 'The Proper Role of Civil Society' section), since they too have directed criticism against the traditional philosophical view of political legitimacy as 'a right to rule', and have attempted to broaden the notion to be applicable to a range of practices in which civil society typically engages.

4 According to these feasibility constraints, principles of political legitimacy must be compatible with the basic features of human nature as we know it as well as be possible to achieve from the status quo (Erman 2016b, p. 57; see also Buchanan 2004; Gilabert and Lawford-Smith 2012). Apart from these constraints, the defended account adopts the accessibility constraint that the suggested principles are desirable and worth pursuing only if they are not morally unapproachable in the sense of involving extreme moral costs (Buchanan 2004).
} 
realizability. But my hope is to show that this kind of broad strokes theorizing about functions in global decision-making still is able to take the normative discussion about political legitimacy forward, for example, by shedding light on problems with the predominant view of the role of civil society for increased political legitimacy, namely, the transmission belt model.

Even on a general outlook, global governance consists of numerous functions that are impossible to account for here. Instead, following from the kind of broad strokes theorizing conducted in this paper, this section brings up what is often considered the six main functions and discusses them in relation to political legitimacy: (1) problem identification, (2) agenda-setting, (3) decision-making, (4) implementation, (5) enforcement and monitoring, and (6) evaluation. The account comprises six normative political principles, together generating political legitimacy in global governance. It is suggested that four of them are applicable to civil society actors depending on their function in global governance.

Let me begin by presenting the principles before specifying what functions they are intended to regulate and offer justifications for their form and contents.

P1 The equal say principle all agents that are subjected to an entity's laws must have an equal say in the decision-making about its basic form and the overarching societal goals and aims.

P2 The principle of public legitimacy all agents that are significantly affected by an entity's policies must have their fundamental interests protected and promoted in a public way in the decision process.

P3 The principle of agency integrity all agents and institutions involved in the overall political process must, independent of their functional role, fulfill a match between their justifying aims and their performance.

P4 The principle of impartiality all agents and institutions realizing law and policy must exercise public power impartially by treating equal cases equally and affected individuals alike irrespective of personal relations, ethnicity, gender, political affiliations, and beliefs.

P5 The principle of basic legitimacy all persons whose fundamental interests are significantly affected by the exercise of public power must not have their basic human rights violated and may demand accountability for alleged violations of these rights.

P6 The liberty principle all persons raising their voice about public matters must have their fundamental liberties secured. ${ }^{5}$

\footnotetext{
5 Note here that while P1-P4 can be applied also to collective agents, P5 and P6 are only applicable to individuals. Moreover, even if it will not be discussed further here, it is worth noting that of the three principles that specify conditions of inclusion (P1, P2 and P5), their criteria of inclusion differ. Whereas P1 takes the form of a so-called 'all subjected' principle, P5 takes the form of a so-called 'all-affected interest' principle. The final principle with an inclusion condition- $\mathrm{P} 2$ - is a kind of mixture of the other two: although affectedness is central, the principle is on a fundamental level more similar to the all subjected principle as it is targeted at agency rather than interests. For a detailed analysis of the criteria of
} 


\section{Pre-Decision Functions and Normative Political Principles}

Problem identification and agenda-setting are both crucial pre-decision functions for any political process. Problem identification concerns the recognition of a certain issue or phenomenon as a problem that is in need of political attention. The problem may be formulated and articulated by a range of different actors and institutions, such as concerned individuals, political parties, public or elite opinion, the mass media, and civil society organizations. In order for the problem to become an object of decision-making, however, it must compete for space on the political agenda. Key actors in agenda-setting are public officials, think tanks, interest groups, political parties, and the media. But also civil society actors may engage in agendasetting. But what normative demands must be met for these agents to do so legitimately?

Indeed, everyone may raise their voice and speak their mind when performing these two functions. Despite the fact that the boundaries of the public space are defined by its reference to the political system, they remain permeable in principle and thus universally open. However, in order for this inclusive property to work properly, basic rights to unrestricted inclusion is crucial, since they aim at preventing exclusion mechanisms and ground a potential for self-transformation (Habermas 1996, p. 374). This is what the liberty principle (P6) is supposed to regulate, which is applicable to all six functions but is particularly important for problem identification and agenda-setting: all persons raising their voice about public matters must have their fundamental liberties secured. The constitution of the public space through the securing of basic liberties provides the appropriate social structure for democracy. First, linking freedom of association and freedom of assembly with freedom of speech secures the framework for various types of associations and actors to push for topics of interest, take part in the formation of public opinion, and so on. Second, basic rights protecting the private space secure the integrity of the lifeworld through freedom of conscience, freedom of movement, and rights of personality (Habermas 1996, p. 386). Personal integrity in the private space is essential for democracy and political legitimacy because it fosters and promotes independent judgment. ${ }^{6}$

Apart from P6, the second principle regulating the pre-decision functions is likewise general in the sense that it is applicable to all functions of the overall political process. This is the principle of agency integrity (P3), which states that all agents and institutions involved in the overall political process must, independent of their functional role, fulfill a match between their justifying aims and their

\footnotetext{
Footnote 5 continued

inclusion accommodated by these principles as well as what 'uptake' conditions in terms of what obligations they generate (e.g. a duty to comply or a duty not to interfere) see Erman (forthcoming).

${ }^{6}$ This constitutes one part of what Habermas famously has called the co-originality of private and public autonomy, between which there is assumed to be a mutual dependency and circular enforcement: 'A wellsecured private autonomy helps 'secure the conditions' of public autonomy just as much as, conversely, the appropriate exercise of public autonomy helps 'secure the conditions' of private autonomy' (Habermas 1996, p. 408). However, the normative status of Habermas's co-originality claim is far from clear, to say the least.
} 
performance. P3 is a revised version of Allan Buchanan's idea of institutional integrity, but with broader scope (Buchanan 2013). The justification for P3 is that it stresses an essential efficacy dimension of political legitimacy that should not be neglected. For while an agent or institution may perform justifiably in relation to other agents and institutions, it may execute its function poorly. And if this is the case, it will lose credibility and hence sociological legitimacy, which is essential for its functioning.

\section{Decision Functions and Normative Political Principles}

Decision-making is indeed the function that most accounts of political legitimacy have focused on in their theorizing. Once problems have been identified and have made it onto the various agendas, laws or policies must be formulated in order to address them. Law and policy proposals are adopted in a variety of ways through decision-making procedures. Examples of decision-making entities in global governance are the Board of Directors of the Bank of International Settlements, NATO's North Atlantic Council, and the Wassenaar Agreement Plenary. An undertheorized aspect of decision-making, which seems relevant for political legitimacy, is the difference between law and policy. This aspect has fallen between two stools in the debate, where philosophers tend to theorize political legitimacy by hypothesizing about international law (Tasioulas 2010, 2013; Christiano 2012; Buchanan 2010; for an exception, see Buchanan 2013), whereas more empirically driven political theorists tend to theorize political legitimacy by hypothesizing about global policy (Stevenson and Dryzek 2012). However, the very distinction between law and policy in relation to political legitimacy is rarely if ever addressed. This is unfortunate, since it is far from obvious that the demands of political legitimacy should be the same with regard to decision-making on law and policy.

From the standpoint of political legitimacy, there are differences between law and policy that are normatively significant. Generally speaking, laws are more formal than policies, constituting a system of rules that sets out standards, procedures and principles that mandate, proscribe or permit specified relationships between people and institutions, provide methods for ensuring impartial treatment, and proscribe punishment for those agents that do not follow the rules of conduct. One could say that these standards, procedures and principles are mainly made for achieving justice in the societal system. By contrast, policies are less formal, often in the form of a statement or document of what is intended to be done in the near or remote future, setting out certain (substantive or procedural) goals that should be achieved. For example, policies may provide private and collective goods. Importantly, though, policies must comply with laws and be formulated and implemented within a legal framework. So, while a policy might identify a new law that is needed, it must do so in adherence to existing laws.

Of course, while the law-making body in a domestic (democratic) context is established and authorized by the constituent power ('the people'), which in turn authorizes additional institutions to carry out other functions, law- and policymaking in the global public domain is widely distributed and the ties between different decision-making bodies are loose at best. Moreover, some laws are not 
laws in the traditional sense but look more like policies (e.g. global administrative law); and some laws are authoritative and binding even without agreement through formalized decision-making (e.g. customary international law). With this in mind, it seems correct to see differences between law and policy in global decision-making in terms of a continuum (Abbott and Snidal 2000) rather than in binary terms. However, it would be a mistake to think that these differences would not matter for political legitimacy just because they are complex and sometimes hard to pin down in a global context.

From the standpoint of legitimacy, international law-making is more fundamental than global policy-making in the sense that it lays out the system of rules that sets out standards, principles and procedures for how policies may be formulated. In the general case, policies must comply with the laws and be formulated and implemented within a legal framework (even if this framework is more fragmented in the global domain). Take, for example, treaties, which are one of the main sources of international law. International organizations, such as the ILO, are established and maintained by treaties (e.g. the Philadelphia Declaration), which create the legal framework setting out the basic rules and standards for the policymaking of the organization.

On the proposed account, five principles regulate the decision-making function, two of which are applicable to this function specifically: P1 and P2. According to the equal say principle (P1), all agents that are subjected to an entity's laws must have an equal say in the decision-making about its basic form and the overarching societal goals and aims. Hence, P1 constitutes a robust democratic principle that aims to secure political equality, i.e. equal decision power. It is worth noting that the equal say principle stays neutral with regard to different formal decision rules, for while we are used to individual-majoritarian rule in domestic contexts, a variety of voting rules are applied to global governance institutions (weighted, majoritarian, unanimity, and so on). Most importantly, in international law institutions the consensus method dominates (Erman 2016b, p. 46). Moreover, agents may be individual or collective according to $\mathrm{P} 1$, such as states in cases where states are the primary subjects of the laws. For sure, in the world as we know it, the primary subjects of international law are states in most areas of decision-making. But while this may be justified in some cases from the standpoint of legitimacy, for example, with regard to some trade law, it may be unjustified in other cases, such as with regard to international human rights law.

The second principle that regulates decision-making specifically on the proposed account is the principle of public legitimacy (P2), which states that all agents that are significantly affected by an entity's policies must have their fundamental interests protected and promoted in a public way in the decision process. In this case too, agents may be either individual or collective. However, in contrast to the equal say principle (P1), the principle of public legitimacy $(\mathrm{P} 2)$ is targeted at policymaking rather than law-making. The publicness condition is essential here. In the theoretical literature on global governance, publicness and transparency are often considered to be crucial for legitimacy. However, they are often discussed in relation to implementation and enforcement or as something that could make up for the loss of democratic control in global governance. But as Christiano has pointed 
out, publicness is important for affected parties in the decision-making phase too in order to see justice be done, i.e. to see that they are fairly treated according to some procedure (Christiano 2008).

The equal say principle (P1) and the principle of public legitimacy (P2) are both justified through the principle of equal respect for autonomous agency, which requires that we regard others as autonomous sources of normative claims in a justificatory practice such that each person is an authority in the space of reasons (Forst 2011). ${ }^{7}$ In contexts where political power is systematically and purposefully exercised, this idea of agency as the exercise of autonomy requires that one is the author of the system of laws to which one is supposed to comply-by being a justificatory equal through equal participation in the legislative procedure-and that one is an authority in the shaping of one's life by having one's fundamental interests promoted.

Apart from these two specific decision-regulating principles, three additional principles are applicable to the decision-making function but not exclusively to this function. Two of them have already been treated: the principle of agency integrity (P3) and the liberty principle (P6). The third principle is the principle of basic legitimacy (P5), stating that all persons whose fundamental interests are significantly affected by the exercise of public power must not have their basic human rights violated and may demand accountability for alleged violations of these rights. In contrast to the other principles of the account, this principle is the only one that is applicable solely to individuals.

If P3 primarily aims at securing efficacy, P5 aims at securing minimal justice in the exercise of public power by securing the fair distributions of burdens and benefits among those involved (Rawls 1971; Dworkin 2000; Tomasi 2001). However, it is directed at minimal standards rather than full justice (cf. Buchanan 2002), according to which entities are considered legitimate when they protect certain fundamental rights (Buchanan 2010, p. 81).

Now, it might be objected to P5 that it is too thin from the standpoint of justice, since it focuses on not violating basic human rights, which presumably would be primarily civil and political rights and a minimal threshold of socio-economic rights, rather than promoting the full range of human rights and reducing severe socio-economic inequalities globally. This observation is correct, as far as it goes. But what is proposed in this paper is an account of global political legitimacy, not an account of global justice. Political legitimacy is foremost about the regulation of public power, responding to the question of 'who exercises power over whom', rather than about the redistribution of primary goods, responding to the question of 'who owes what to whom' (Erman 2016b, p. 58). Furthermore, according to the accessibility constraint on my ideal-theoretical approach (see note 4), the suggested principles are only desirable and worth pursuing if the moral costs are not too high. Hence, we can well imagine situations where the cost of striving towards fulfilling them would simply be too costly in terms of injustice such that our concerns for global justice would trump our concerns for political legitimacy.

\footnotetext{
7 However, this is just one way of grounding P1 and P2. I believe many other basic egalitarian principles will be able to ground them too.
} 


\section{Post-Decision Functions and Normative Political Principles}

Let us move from decision-making to the post-decision functions of implementation, enforcement and monitoring, and evaluation. With regard to implementation, executive agents and institutions implement laws and policies, for example, by adopting rules and regulations, providing services and products, and so on. Typical implementation bodies in global governance are the secretariats, such as the secretariats of the Council of Europe, the OECD, and ASEAN. The United Nations Secretariat, for example, is responsible for the implementation of the decisions of the General Assembly, the Economic and Social Council, and the Security Council. Enforcement typically refers to the application of rewards for compliance and threats of sanctions and penalties for non-compliance. Consider foremost the judiciary or juridical institutions, which are the institutions that interpret, evaluate, and apply international law as well as ensure equal justice under law, such as the International Criminal Court. Enforcement of international law is often of a coercive kind, as actual or threatened imposition of costs to promote compliance. While most costs are material, as with economic sanctions, also diplomatic means in the form of social pressure and shaming are used. In contrast to the domestic case, however, enforcement institutions are decentralized rather than centralized. Supranational enforcement authorities, such as the International Court of Justice, are still rather weak, lacking compulsory jurisdiction (Thompson 2013, pp. 503-504). With regard to monitoring, examples of monitoring bodies in global governance include the OAS Inter-American Commission on Human Rights and the judicial chambers of the International Criminal Court.

Apart from the principles of liberty (P6), agency integrity (P3), and basic legitimacy (P5), which of course are crucial for post-decision functions too in order to secure basic liberties, efficacy, and minimal justice, one additional principle is applicable: the principle of impartiality (P4) says that all agents and institutions realizing ${ }^{8}$ law and policy must exercise public power impartially by treating equal cases equally and affected individuals alike irrespective of personal relations, ethnicity, gender, political affiliations, and belief (see Habermas 1996; Barry 1995). The impartiality condition is essential for political legitimacy, yet it is not much discussed in the current literature on legitimacy and democracy in global governance. ${ }^{9}$ Insofar as it is brought up for scrutiny, it is in the empirical political science literature rather than in normative theory (Rothstein and Teorell 2008).

In empirical research, studies have shown that social capital, defined as generalized trust in other people and access to social networks, is determined by the quality of the governmental institutions rather than the other way around (Delhey and Newton 2005; Rothstein 2005). Moreover, it has been demonstrated that democracy in terms of the equal access to power (political equality) is not sufficient for good governance. Since the equal access to power might serve only the interests of the few, and has no means to regulate the exercise side of power, it cannot prevent corruption, clientilism, favoritism, and patronage (Diamond 2007, 2010).

\footnotetext{
${ }^{8}$ Realizing here refers to implementation, enforcement, and monitoring.

${ }^{9}$ Compare with the justice literature and moral theory in general where impartiality plays a large role.
} 
Hence, even if the equal access to power would secure impartiality on the input side, it does not entail impartiality on the output side, that is, in how authority is exercised. Yet, output impartiality is shown to be one of the most important factors for explaining good governance (Rothstein and Teorell 2008, 2012). Empirical scholars have found that impartial and effective executive institutions matter more than representational institutions for how satisfied citizens are with their democratic government (Dahlberg and Holmberg 2014). Here normative and sociological notions of political legitimacy thus seem to coincide or at least overlap, since impartiality in the exercise of power is not only effective by being trust-enhancing but also essential for normative reasons: everyone in a democratic polity is a member on equal footing and should therefore be treated impartially in equal cases.

As noted in 'The Function-Sensitive Approach: Basic Assumptions' section, the proposed function-sensitive approach assumes that the content and justification of principles of political legitimacy is dependent on the different functions in global governance as well as the relationship between them. So far, we have treated the first assumption. Before we move to the second, let me summarize the proposal so far:

\begin{tabular}{llllll}
\hline $\begin{array}{l}\text { Principles of } \\
\text { legitimacy }\end{array}$ & $\begin{array}{l}\text { Problem } \\
\text { identification and } \\
\text { agenda-setting }\end{array}$ & $\begin{array}{l}\text { Law- and } \\
\text { policy- } \\
\text { making }\end{array}$ & Implementation & $\begin{array}{l}\text { Enforcement } \\
\text { and } \\
\text { monitoring }\end{array}$ & Evaluation \\
\hline $\begin{array}{l}\text { P1. The equal say } \\
\text { principle }\end{array}$ & $\begin{array}{c}\text { Applicable } \\
\text { (law) }\end{array}$ & & \\
$\begin{array}{l}\text { P2. The principle } \\
\text { of public } \\
\text { legitimacy }\end{array}$ & Applicable & & & \\
$\begin{array}{l}\text { P3. The principle } \\
\text { of agency } \\
\text { integrity }\end{array}$ & Applicable & Applicable & Applicable & Applicable & Applicable \\
$\begin{array}{c}\text { P4. The principle } \\
\text { of impartiality }\end{array}$ & Applicable & Applicable & Applicable & Applicable \\
$\begin{array}{c}\text { P5. The principle } \\
\text { of basic } \\
\text { legitimacy }\end{array}$ & Applicable & Applicable & Applicable & Applicable & Applicable \\
$\begin{array}{l}\text { P6. The liberty } \\
\text { principle }\end{array}$ & & Applicable & Applicable & Applicable \\
\hline
\end{tabular}

\section{The Justificatory Relationship Between Functions}

The second assumption about the relationship between functions is crucial since an analysis of an isolated function does not tell us enough about its justificatory status in order to determine what political legitimacy requires. Let me explain. If an agent or institution performs implementation or enforcement, and does so perfectly, but has no mandate to do so, this would be problematic from the standpoint of political legitimacy. Indeed, dictatorships are problematic even if the implementation of law 
and policy works effectively. This means that what legitimacy requires cannot solely be decided by the normative political principles regulating the main functions, but also by the justificatory status of each function in relation to other functions. The account developed here distinguishes between two kinds of rightful authority in elaborating the relationship between functions: authorized entities (agents or institutions) and mandated entities (agents or institutions). A decisionmaking entity is authorized insofar as it fulfills the equal say principle (P1). This means that even if an entity produces policy rather than law, it must be established and maintained through P1 since its policies are supposed to be formulated within the limits of the law. Mandated entities, on their part, are entities delegated public power from authorized entities. Mandated entities have authority with regard to implementation, enforcement, monitoring and evaluation. The bond between authorized and mandated entities, I argue, creates a justificatory link that is essential for political legitimacy, since it establishes an important justificatory hierarchy between functions (and thereby between authorities). The constituent power is the main normative source of political legitimacy-on my account those agents subjected to the laws in line with the equal say principle (P1) - as it authorizes law-making entities, which in turn have supremacy over other entities and lend them legitimacy through delegation (Erman 2016a).

To illustrate this justificatory link, consider an international organization such as the WTO. Even if the WTO would fulfill a number of normative political principles important for political legitimacy both internally and externally, we cannot draw conclusions about its legitimacy without knowledge about how it was established. Or consider international courts; even if they would fulfill principles of legitimacy in their performance, for example, by realizing the objectives of the treaty in question and securing accountability, transparency, and legality (Follesdal 2014, 2016; Squatrito and Langvatn 2015), their adjudication would not be legitimate unless the law that was interpreted and applied sprung from a legitimate source. Hence, the suggested justificatory link between functions takes into account the importance of not having what Buchanan calls 'tainted origins' (Buchanan 2013, pp. 188-189).

\section{The Proper Role of Civil Society}

With these relational properties of the suggested account in place, together with the functional properties elaborated earlier, we are equipped to return to the question raised in the introduction about the normative role of civil society actors for strengthening political legitimacy in global governance, hence turning the wellstudied empirical question about civil society access to global governance arrangements (Tallberg et al. 2013; Koremenos 2013; Bloodgood 2011) into a hitherto neglected normative one.

Let us begin with pre-decision functions. As mentioned earlier, many different agents and institutions are involved in problem identification and agenda-setting, including civil society actors. On the function-sensitive account developed here, it is in the pre-decision phase that civil society may play its most important role for 
strengthening the political legitimacy of global governance. Civil society organizations often have exactly the kind of local knowledge and expertise that is called for in relation to different policy domains to detect specific problems of concern and formulate them in political terms, as well as the kind of human resources and engagement to push for their inclusion on the political agenda.

While the role of civil society with regard to pre-decision functions is relatively uncontroversial, involvement in decision-functions raises some serious questions about normative status and justification. Both decision-regulating principles of my account - the equal say principle (P1) and the principle of public legitimacy (P2) are justified through the principle of equal respect for autonomous agency, which requires that one is the author of the system of laws to which one is supposed to comply (by being a justificatory equal through equal participation in the legislative procedure) and that one is an authority in the shaping of one's life by having one's fundamental interests promoted. As we have seen, the equal say principle (P1) is the more fundamental of the two in the sense that it generates the system of laws within which policies must be formulated. It embodies the notion of political equality, which broadly alludes to equal decision power over the basic form of overarching societal goals and aims among those subjected to the system of laws.

Independent of which model of democracy we favor (deliberative democracy, radical democracy, liberal representative democracy, and so on), political equality is commonly regarded as an essential property of democracy. It presumes that all those subjected to a system of laws should have an equal say in the decision-making (directly or indirectly) about the overarching societal goals and aims, as well as to be equally entitled to express their concerns in the public space. Whether they do the latter through membership of a civil society organization, a union, an interest group, or a club does not matter from the standpoint of political legitimacy. ${ }^{10}$ However, with regard to having an equal say in the decision-making, civil society actors do not have a privileged position which lends them a special normative status such that they should be included as decision-makers. In order to defend such a view, one would have to offer an argument for why political equality is not an essential property of democracy (see Saunders 2010, for such an attempt).

With regard to post-decision functions, these raise important questions about the competence and capacity of civil society organizations. In global governance, entities established through the equal say principle (P1) are authorized decisionmaking bodies on the defended account. However, since implementation and enforcement agents are scattered in the global domain rather than uniformly knit to a decision-making apparatus like in a domestic context, it is often the case that many different kinds of agents and entities are delegated public power by authorized entities to perform executive functions (thereby becoming mandated authorities), e.g. by adopting rules and regulations or providing products and services. Global administrative bodies, for example, make rules and regulations within the framework of a treaty that establishes the institution and implements the general

\footnotetext{
${ }^{10}$ Of course, there are normative limits to this, since one may for example be a resident alien and not have an equal say in the decision-making, or be a tourist, and the like. This is what the debate on the socalled 'boundary problem' in democratic theory is about, which deals with criteria of inclusion, see note 10. See also, e.g. Erman (2014a, b), Goodin (2007), Whelan (1983), Abizadeh (2012).
} 
treaty law through mandated rule alteration and regulation. Whilst such bodies have some kind of independence, they are constrained to effectively and genuinely pursue the aims and realize the principles established by the principal parties (Christiano 2015; Erman 2016b, p. 54). On the proposed function-sensitive account, also well-organized civil society organizations with implementation competence and capacity may in principle be mandated to perform tasks such as making regulations, providing services, or enforcing rules. While this most likely will take place within a limited domain in relation to specific policies - at least in our current world-it still extends the normative potential of civil society for political legitimacy beyond pre-decision functions.

That said, civil society actors as we know them today are more likely to assist in enforcement, monitoring, and evaluation. In fact, apart from playing an important role performing the pre-decision functions of problem identification and agendasetting, discussed earlier, they can strengthen political legitimacy in global governance by performing these post-decisional functions too, insofar as they become mandated authorities to do so (rather than being self-proclaimed and selfappointed). This already takes place today. According to recent empirical research, the bodies of international organizations responsible for enforcement and for monitoring member state compliance, such as the WTO Appellate Body and the Andean Court of Justice, are by far the most open to transnational actors such as civil society organizations (Tallberg et al. 2013, p. 77).

In sum, from the account of political legitimacy proposed here, civil society actors may strengthen the political legitimacy of global governance by performing five out of the six scrutinized functions under certain conditions and insofar as they fulfill the applicable principles: problem identification, agenda-setting, implementation, enforcement and monitoring, and evaluation.

\section{Competing Accounts: The Transmission Belt Model}

Let me now move from the main constructive claim of the paper to the critical claim. I want to show how the suggested role for civil society departs drastically from the most popular view of the role of civil society, the transmission belt model, as well as shed light on some problems with this model.

If democratic theory took a deliberative turn in the 1990s, it is not too far-fetched to say that it has taken a 'civil society turn' in the last decades when theorizing democracy in global governance. In light of the present circumstances of world politics, consisting of a growing asymmetry between rule-makers and rule-takers and inequalities among states, many political theorists investigate the role of transnational civil society actors-ranging from social movements to non-governmental organizations (NGOs) - for achieving more transnational or global democracy. Transnational civil society actors are increasingly seen as a vital component of international politics. They both steadily increase in numbers and, some would argue, in political importance. Today, they interact with virtually all international organizations with various degrees of institutionalization and formalization (Charnovitz 1997; Tallberg et al. 2013). The European Union, for example, consults a wide range of civil society actors, and in global economic governance, 
the World Bank has established far-reaching interactions for at least two decades (Steffek et al. 2010, p. 100).

The most popular version of the civil society view in the current theoretical literature is the transmission belt model. According to this model, deliberative democracy is the most viable theoretical tool for theorizing political legitimacy and democracy in global governance, since a deliberative understanding of democratic collective decision-making is particularly well-suited for the non-hierarchical, nonelectoral, and non-territorial features of world politics (Nanz and Steffek 2004, p. 318). Instead of promoting democratization through institution-building and lawmaking, the transmission belt model focuses on democratization through the strengthening of the discursive quality of global political processes via civil society. The model is depicted as consisting of three main properties: the public space, in which informal processes of will- and opinion-formation among citizens take place, the empowered space, in which authoritative collective decision-making takes place, and civil society acting as a transmission belt between these two spaces (Dryzek 2006, 2011; Nanz and Steffek 2004, 2008; Bäckstrand 2011; Bäckstrand et al. 2006; Kuyper 2016, p. 308).

According to this model, transnational civil society actors mitigate the democratic deficit in global governance insofar as they function as an intermediary between the public space (transnational citizenry) and the empowered space (global decision-makers), allowing the former to affect the deliberations and decisionmaking within the latter (Dryzek 2011, p. 226; Nanz and Steffek 2008, p. 8). It is argued that the transmission belt sidesteps the bottleneck of interest aggregation and representation through hierarchical state structures and instead channels political demands directly into international forums (Steffek et al. 2010, p. 101). In global climate governance, for example, 'civil society can exercise discursive influence on formal negotiations and collective decision making as well as promoting a transnational public sphere independent from sovereign authority' (Bäckstrand 2011, p. 6; see also Bäckstrand et al. 2006).

The function of civil society actors to transmit citizens' concerns and interests into the decision process of the empowered space is served in two main ways. To begin with, it is stressed that civil society actors should act as transmitters by lending a voice to the global citizenry and take into consideration the input of stakeholder concerns through informal processes, aiming at opening up relevant discourses to a wider public and pushing for more transparency in global decisionmaking. In order to successfully represent and speak for the global citizenry, however, and 'push global governance towards democratization,' civil society actors must also have a formal role in the decision process: their participation must be institutionalized so that they get formal access to the decision-making arenas (Nanz and Steffek 2008, p. 14). Any democratization via civil society involvement requires participation rights for non-state actors and clearly defined rules of collaboration, to govern the interaction between civil society actors and international organizations. Hence, the former must be acknowledged as 'legitimate interlocutors in political debate' (Nanz and Steffek 2008, p. 14).

In order for civil society actors to contribute to the political legitimacy of global governance by engaging in these informal and formal processes, proponents argue, 
they have to fulfill certain criteria or principles so that they themselves become legitimate actors. Since these actors are supposed to constitute a transmission belt in global governance and give voice to citizens, 'we cannot avoid the question of their internal functioning,' as the transmission belt model presumes that such actors have the capacity 'to represent elements of a global citizenry' (Steffek et al. 2010, p. 104). And it is here that deliberative democracy becomes most useful conceptually and normatively, since it is not premised on a traditional numerical understanding of political representation but on the representation of interests, values, or discourses.

On Nanz and Steffek's view, civil society actors are voluntary associations mobilizing around certain problems and concerns, and may only claim to be representative of their supporters, members, and beneficiaries (Steffek et al. 2010, p. 104). They must consult their supporters, members, and beneficiaries on policyrelevant decisions as well as be accountable to their constituency in order to be legitimate. This capacity to fulfill the 'transmission belt ideal' is measured in terms of five normative criteria: participation, inclusion, responsiveness, transparency, and independence (Steffek et al. 2010, p. 101).

When exercising formal decision power, advocates of the transmission belt model usually put higher demands of democratic legitimation on civil society actors than when they act as non-electoral representatives via informal channels, since then these actors take part in the exercise of (coercive) collective decision-making (Kuyper 2016, p. 308). ${ }^{11}$ Hence, the legitimacy demands differ in the empowered and public spaces. Whereas actors in both spaces may not harm those they affect, according to Jonathan Kuyper, they only owe democratic standing to those affected if they become subjected to coercive decision-making in the empowered space. This is so because only actors who can make coercive rules, laws, and decisions should become legitimate by being held responsible to deliberative capacity in a demanding sense, which requires the fulfillment of three criteria: inclusivity, authenticity, and consequentiality (Kuyper 2016, drawing heavily on Dryzek 2009). First, inclusion is considered essential, since without equal inclusion we may have 'deliberation but not deliberative democracy,' according to Kuyper (2016, p. 313). This criterion generates the duty of non-electoral representatives (e.g. civil society organizations) to include the interests of their constituency and not to exclude the interests of other subjected actors from the empowered space (Kuyper 2016, p. 315). This duty implies that a wide array of interests are articulated and ventilated so that individuals and groups can confront each other's views and have an equal opportunity to influence the outcomes of the deliberation. The criterion of authenticity, secondly, demands that interlocutors deliberate in a non-coercive, reciprocal and generalizable manner. Their arguments must consist of 'generalizable claims that connect their position with the interests of subjected and affected parties' and thus move beyond self-interest (Kuyper 2016, p. 315). Finally, the criterion of consequentiality requires that the outcomes of deliberation 'reflect the process of deliberative preference formation' (Kuyper 2016, p. 313). In sum, insofar

\footnotetext{
11 Non-electoral representation usually refers to all actors who are not elected but still make representative claims (Kuyper 2016; Saward 2010).
} 
as civil society actors act as non-electoral representatives in the empowered space, taking part in the decision-making, this threefold requirement must be fulfilled in order for them to contribute to the overall political legitimacy of the system (by acting legitimately).

\section{What is Wrong with the Transmission Belt Model?}

Being faithful to the ideal of deliberative democracy, a shared assumption among proponents of the transmission belt model is that democracy consists of a public space and an empowered space, and that political legitimacy is generated if and only if and because (a) deliberation takes place in both spaces, i.e. through informal and formal practices of opinion- and will formation, and (b) the formal institutionalized procedures of opinion- and will-formation are sensitive to the informal flows in which citizens' concerns are articulated such that they are reflected in the law- and policy-making. However, on what grounds do advocates of the transmission belt model assume that civil society actors have the special status of acting as a transmission belt here, transmitting citizens' concerns by making representative claims on behalf of them? We need to be offered an argument for why a civil society organization acting as non-electoral representative is justified in representing others' claims from a democratic viewpoint.

For sure, there are many considerations involved here, not least pragmatic ones pertaining to feasibility and non-ideal theory. But even if certain feasibility constraints are implicitly presumed by the transmission belt model, these are never articulated and defended. The usual claim is that since global governance in our current world lacks electoral mechanisms, civil society may well act as nonelectoral representatives and pursue equivalent functions (Dryzek 2006, 2011; Stevenson and Dryzek 2012; Kuyper 2016; Macdonald 2008; Scholte 2002, 2005, 2014). However, not only is this claim unsupported, the electoral/ non-electoral framework misses the essence of what is at stake, since it is not electoral mechanisms as such that are crucial from the standpoint of democracy, but political equality, i.e. that citizens have equal decision power (directly or indirectly) over public affairs. Electoral mechanisms have only historically been the best means to achieve this. Indeed, to say that we do not need it because we do not have it is question-begging unless we are offered a justification for why political equality can be secured by other means (or why political equality is not an essential property of democracy). Without such a justification, we do not know why, more exactly, the prescribed role for civil society leads to increased political legitimacy in global governance.

I believe the transmission belt picture leads us in the wrong direction for theorizing the proper normative role of civil society in relation to political legitimacy, since it generates erroneous prescriptions. Of course, this does not take away the fact that civil society has an important role to play, as I have tried to show above; it only means that it is not best depicted as a transmission belt between the public space (citizens) and the empowered space (the decision-making entity). Rather, if we are to use the transmission belt image at all for describing the proper role of civil society, this belt is better described as located between the private space 
(individuals in the lifeworld) and the public space (citizens). It is here that the role of civil society is both crucial for the functioning of democracy and justifiable from the standpoint of political legitimacy. As I argue below, without a robust civil society located here, the public space could not perform its democratic function.

The public space is a communication structure rooted in the lifeworld through the associational networks of civil society, consisting of NGOs, non-economic actors, and voluntary associations that knit the public space to the private space (Habermas 1996, p. 359). These more or less spontaneously arising movements, associations, and organizations stay attuned to the ways in which societal problems resonate in the private space, extract and transmit these reactions in amplified form to the public space (Habermas 1996, p. 367). But rather than formalizing this involvement, as recommended by the transmission belt model, civil society must rather be sufficiently independent of the empowered space to successfully act as a transmission belt between the private and the public space. Only if the public space develops spontaneously and reproduces itself from its own resources, in unregulated and unorganized ways, with support from a vital civil society, could civil society play its 'autonomous' normative and epistemic functions (Erman 2016a, p. 278; Habermas 1996, p. 369). In contrast to the empowered space, the public space is not a body but a medium for multiple voices and opinions.

When the public space works well for strengthening the political legitimacy of the political system, it not only detects and identifies problems in the lifeworld with assistance from civil society, but also attempts to thematize these problems and suggest possible solutions in such a way that they might be taken up by formal decision processes of the empowered space (Habermas 1996, p. 359). However, from the perspective of democratic theory, civil society has no privileged status visà-vis any other citizen or group to further attempt to influence the empowered space by making representative claims about these concerns-even if they fulfilled the criteria of transparency, inclusion, authenticity, consequentiality, responsiveness, and the like, suggested by transmission belt proponents. The public space is a fully open sounding board for problems in society that must be dealt with by the political decision-makers, in which everyone is equally entitled to express their views and has an equal opportunity to do so.

To function well as a transmission belt between the private and public spaces, civil society actors do not need to make their representative claims in, for example, a generalizable way to contribute to political legitimacy in global governance, as suggested by Dryzek and Kuyper. What they need to do, though, is to transform individual problems into questions of public interest inside the communicative structure of the public space so that they could be thematized and dramatized in a sufficiently persuasive manner to be taken up by the formal decision bodies of the empowered space. This is not a normative criterion for political legitimacy but simply a way to indirectly affect the empowered space by highlighting questions of public concern. When civil society works well, it is precisely in this way that it assists the public space to perform its 'democratic' function in the political system as a whole. Once such informally shaped public opinions do get picked up by the empowered space, however, they must be filtered through the formal procedures of opinion- and will-formation (which secures political equality) to transform into 
legitimate political decisions (Habermas 1996, p. 371). It is then that they must be tested from the standpoint of the generalizability of interests or as forms of generalizable claims (i.e. not reducible to private interests).

\section{Winding up}

In this paper, I have made two claims. First and foremost, I have tried to demonstrate the fruitfulness of adopting a function-sensitive approach when theorizing political legitimacy in global governance and the proper normative role of civil society, according to which the content and justification of principles of political legitimacy is dependent on different functions in global governance as well as the relationship between these functions. In view of the proposed account, I have tried to identify some problems with the transmission belt model, which has gained a lot of attention in international political theory in recent years. I have argued that this model leads to erroneous prescriptions and should be abandoned.

From the proposed account, what normative assessments may we make of civil society and our current global governance arrangements? The first assessment is that civil society works best for political legitimacy in the pre-decision phase if it is sufficiently independent of the empowered space, so that it can reflexively perform its autonomous normative and epistemic functions as well as support the public space as a medium for multiple voices and opinions. Hence, against the tendency to formalize civil society's access to international organizations, we should be cautious of institutionalizing the involvement of civil society actors in problem identification and agenda-setting. While such a formalized involvement may be desirable for many reasons-e.g. for stability or popularity among citizens-it does not contribute to the political legitimacy of global governance. Instead, what political legitimacy requires is the fulfillment of the liberty principle (P6), and the principle of agency integrity (P3) in the pre-decision phase. Second, we should be critical of the growing involvement of civil society actors in the decision-making bodies of international organizations. Against this tendency, which is also supported by the transmission belt model, I have suggested that there are no grounds for such decision power from the standpoint of democracy. Third, while civil society organizations may be involved in implementation as well as in enforcement, monitoring and evaluation-as they increasingly are-they may only rightfully perform these tasks if they are delegated public power by authorized entities, thereby becoming mandated entities, and secure efficacy, impartiality, minimal justice, and basic liberties by satisfying the principle of agency integrity (P3), the principle of impartiality (P4), the principle of basic legitimacy (P5), and the liberty principle (P6).

Acknowledgements I owe special thanks to the participants of the workshop 'The Ethics of Political Participation' organized by Phil Parvin at Loughborough University in 2016. Thanks also to the editors and anonymous referees of the journal for valuable comments and guidance. In addition, I am grateful for the generous funding of this research from the Swedish Research Council and Marianne and Marcus Wallenberg Foundation. 
Open Access This article is distributed under the terms of the Creative Commons Attribution 4.0 International License (http://creativecommons.org/licenses/by/4.0/), which permits unrestricted use, distribution, and reproduction in any medium, provided you give appropriate credit to the original author(s) and the source, provide a link to the Creative Commons license, and indicate if changes were made.

\section{References}

Abbott, Kenneth, and Duncan Snidal. 2000. Hard and Soft Law in International Governance. International Organization 54(3): 421-456.

Abizadeh, Arash. 2012. On the Demos and Its Kin: Nationalism, Democracy, and the Boundary Problem. American Political Science Review 104: 867-882.

Beitz, Charles. 2014. Internal and External. Canadian Journal of Philosophy 44(2): 225-238.

Bäckstrand, Karin. 2006. Democratizing Global Environmental Governance? Stakeholder Democracy After the World Summit on Sustainable Development. European Journal of International Relations 12: $467-498$.

Bäckstrand, Karin. 2011. The Democratic Legitimacy of Global Governance after Copenhagen. In The Oxford Handbook of Climate Change and Society, ed. J. Dryzek, R. Norgaard, and D. Schlosberg. Oxford: Oxford University Press.

Barry, Brian. 1995. Justice as Impartiality. Oxford: Oxford University Press.

Buchanan, Allen. 2002. Political Legitimacy and Democracy. Ethics 112: 689-719.

Buchanan, Allen. 2004. Justice, Legitimacy, and Self-Determination. Oxford: Oxford University Press.

Buchanan, Allen. 2010. The Legitimacy of International Law. In Philosophy of International Law, ed. S. Besson and J. Tasioulas. Oxford: Oxford University Press.

Buchanan, Allen. 2013. The Heart of Human Rights. Oxford: Oxford University Press.

Buchanan, Allen, and Robert O. Keohane. 2006. The Legitimacy of Global Governance Institutions. Ethics and International Affairs 20: 405-437.

Charnovitz, Steve. 1997. Two Centuries of Participation: NGOs and International Governance. Michigan Journal of International Law 18: 183-286.

Christiano, Thomas. 1996. The Rule of the Many: Fundamental Issues in Democratic Theory. Boulder, CO: Westview Press.

Christiano, Thomas. 2008. The Constitution of Equality: Democratic Authority and Its Limits. Oxford: Oxford University Press.

Christiano, Thomas. 2012. Rational deliberation among experts and citizens. In Deliberative Systems, ed. J. Mansbridge and J. Parkinson, 27-51. Cambridge: Cambridge University Press.

Christiano, Thomas. 2015. Legitimacy and the International Trade Regime. San Diego Law Review 52: 981.

Dahlberg, Stefan, and Sören Holmberg. 2014. Democracy and Bureaucracy: How Their Quality Matters for Popular Satisfaction. West European Politics 37: 515-537.

Delhey, Jan, and Kenneth Newton. 2005. Predicting Cross-National Levels of Social Trust: Global Pattern or Nordic Exceptionalism? European Sociological Review 21: 311-327.

Diamond, Larry. 2007. A Quarter-Century of Promoting Democracy. Journal of Democracy 18: 118-120.

Diamond, Larry. 2010. Democratization in Africa: Progress and Retreat. Baltimore, MD: Johns Hopkins University Press.

Dryzek, John. 2006. Deliberative Global Politics: Discourse and Democracy in a Divided World. Cambridge: Polity Press.

Dryzek, John. 2009. Democratization as Deliberative Capacity Building. Comparative Political Studies 42: 1379-1402.

Dryzek, John. 2011. Global Democratization: Soup, Society, or System? Ethics and International Affairs 25(2): 211-234.

Dworkin, Ronald. 2000. Sovereign Virtue. Cambridge, MA: Harvard University Press.

Erman, Eva. 2014a. The Boundary Problem and the Ideal of Democracy. Constellations 21(4): 535-546.

Erman, Eva. 2014b. The Boundary Problem and the Right to Justification. In Justice, Democracy and the Right to Justification, ed. D. Owen. London: Bloomsbury Academic. 
Erman, Eva. 2016a. Representation, Equality, and Inclusion in Deliberative Systems: Desiderata for a Good Account. Critical Review of International Social and Political Philosophy 19(3): 263-282.

Erman, Eva. 2016b. Global Political Legitimacy Beyond Justice and Democracy? International Theory 8(1): 29-62.

Erman, Eva. Forthcoming. A Function-Sensitive Approach to the Political Legitimacy of Global Governance. British Journal of Political Science.

Follesdal, Andreas. 2014. Legitimacy Challenges and What to Do About Them: Accountability and Authority of the European Court of Human Rights. In Proceedings of Conference on the Long-term Future of the European Court of Human Rights, 78-85.

Follesdal, Andreas. 2016. Building Democracy at the Bar: The European Court of Human Rights as an Agent of Transitional Cosmopolitanism. Transnational Legal Theory 7(1): 95-113.

Forst, Rainer. 2011. The right to justification: Elements of a constructivist theory of justice, ed. A. Allen, (trans: J. Flynn). New York: Columbia University Press.

Gilabert, Pablo, and Holly Lawford-Smith. 2012. Political Feasibility: A Conceptual Exploration. Political Studies 60: 809-825.

Goodin, Robert. 2007. Enfranchising All Affected Interests and Its Alternatives. Philosophy and Public Affairs 35: 40-68.

Green, Jessica, and Jeff Colgan. 2013. Protecting Sovereignty, Protecting the Planet: State Delegation to International Organizations and Private Actors in Environmental Politics. Governance 26: 473-497.

Greenwood, Justin. 2007. Organised Civil Society and Democratic Legitimacy in the EU. British Journal of Political Science 37: 333-357.

Habermas, Jürgen. 1996. Between Facts and Norms: Contributions to a Discourse Theory of Law and Democracy (trans: Rehg, W.). Cambridge, MA: MIT Press.

Hurrell, Andrew, and Terry Macdonald. 2012. Global Public Power: The Subject of Principles of Global Political Legitimacy. Critical Review of International Social and Political Philosophy 15: 553-571.

Kohler-Koch, Beate. 2007. The Organization of Interests and Democracy in the European Union. In Debating the Democratic Legitimacy of the European Union, ed. B. Kohler-Koch and B. Rittberger, 255-271. Lanham, MD: Rowman \& Littlefield.

Koremenos, Barbara. 2013. The Continent of International Law. The Journal of Conflict Resolution 57: $653-681$.

Kuyper, Jonathan. 2016. Systemic Representation: Democracy, Deliberation, and Nonelectoral Representatives. American Political Science Review 110: 308-324.

Macdonald, Terry. 2008. Global Stakeholder Democracy. Oxford: Oxford University Press.

Nanz, Patricia, and Jens Steffek. 2004. Global Governance, Participation and the Public Sphere. Government and Opposition 39: 314-334.

Nanz, Patricia, and Jens Steffek. 2008. Emergent Patterns of Civil Society Participation in Global and European Governance. In Participation in European and Global Governance, ed. Civil Society. New York, NY: Palgrave Macmillan.

Rawls, John. 1971. A Theory of Justice. Cambridge, MA: Harvard University Press.

Rothstein, Bo. 2005. Social Traps and the Problem of Trust. Cambridge: Cambridge University Press.

Rothstein, Bo, and Jan Teorell. 2008. What is Quality of Government? A Theory of Impartial Government Institutions. Governance 21: 165-190.

Rothstein, Bo, and Jan Teorell. 2012. Defining and Measuring Quality of Government. In Good Government: The Relevance of Political Science, ed. S. Holmberg and B. Rothstein. Cheltenham: Edward Elgar.

Saunders, Ben. 2010. Democracy, Political Equality, and Majority Rule. Ethics 121: 148-177.

Saward, Michael. 2010. The Representative Claim. Oxford: Oxford University Press.

Scholte, Jan Aart. 2002. Civil Society and Democracy in Global Govenance. Global Governance 8: 281-304.

Scholte, Jan Aart. 2005. Civil Society and Democratically Accountable Global Governance. In Global Governance and Public Accountability, ed. D. Held and M. Koenig-Archibugi. Oxford: Blackwell.

Scholte, Jan Aart. 2014. Reinventing Global Democracy. European Journal of International Relations 20: 3-28.

Squatrito, Theresa, and S. Langvatn. 2015. Conceptualizing and Measuring the Legitimacy of International Criminal Courts. In Legitimacy of Criminal Tribunals, ed. N. Hayashi and C. Bailliet. Cambridge: Cambridge University Press. 
Steffek, Jens, et al. 2010. Assessing the Democratic Legitimacy of Transnational CSOs: Five Criteria. In Evaluating Transnational NGOs: Legitimacy, Accountability, Representation, ed. J. Steffek and H. Hahn. Basingstoke: Palgrave Macmillan.

Stevenson, Hayley, and John Dryzek. 2012. The Discursive Democratisation of Climate Governance. Environmental Politics 2: 189-210.

Tallberg, Jonas, et al. 2013. The Opening Up of International Organizations to Transnational Actors. Cambridge: Cambridge University Press.

Tasioulas, John. 2010. The Legitimacy of International Law. In Philosophy of International Law, ed. S. Besson and J. Tasioulas. Oxford: Oxford University Press.

Tasioulas, John. 2013. Human Rights, Legitimacy, and International Law. The American Journal of Jurisprudence 58: 1-25.

Thompson, Alexander. 2013. Coercive Enforcement of International Law. In Interdisciplinary Perspectives on International Law and International Relations, ed. J. L. Dunoff and M. A. Pollack. New York, NY: Cambridge University Press.

Tomasi, John. 2001. Liberalism Beyond Justice: Citizens, Society, and the Boundaries of Political Theory. Princeton, NJ: Princeton University Press.

Valentini, Laura. 2012. Assessing the Global Order: Justice, Legitimacy, or Political Justice? Critical Review of International Social and Political Philosophy 15: 593-612.

Wellman, Christopher. 1996. Liberalism, Samaritanism, and Political Legitimacy. Philosophy and Public Affairs 25: 211-237.

Whelan, Frederick. 1983. Democratic Theory and the Boundary Problem. In Liberal Democracy, ed. J. R. Pennock and J. W. Chapman. New York, NY: New York University Press. 